\title{
The Presentation of Shoah Events to Students at Various Educational Levels: A Review
}

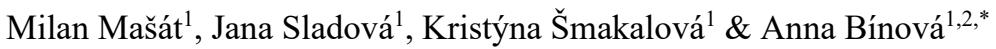 \\ ${ }^{1}$ Palacký University Olomouc, Faculty of Education, Žižkovo náměstí 5, 771 40, The Czech Republic \\ ${ }^{2}$ Elementary School and Kindergarten Batelov, Allowance Organization, Školní 373, 58851 Batelov, The Czech \\ Republic
}

Correspondence: Milan Mašát, Univerzita Palackého v Olomouci, Žižkovo náměstí 5, 77140 Olomouc. E-mail: milan.masat01@upol.cz; milan0m@seznam.cz

Received: April 1, 2020

Accepted: April 14, $2020 \quad$ Online Published: May 26, 2020

doi:10.5430/wje.v10n3p1

URL: https://doi.org/10.5430/wje.v10n3p1

\begin{abstract}
The review study deals with the presentation of methods of acquainting pupils and students with the Shoah events at various levels of institutional education. Based on the opinions and positions of leading experts on the subject, we summarize the most important methods in the field. In the introduction we present the importance of one line of the events of World War II in the 21 st century world: the defined phenomenon can be perceived as a warning against certain forms of stigmatization, ostracism or as a warning against the need to protect democratic political order. In the paper we define the terms Shoah, Holocaust, anti-Semitism and racism. We also deal with the Israeli public schools in the area of teaching about the Shoah, with the curricular anchorage of the terms Shoah and Holocaust and with the potential of Literary Education in the field of Shoah presentation. We believe that the educational system of the Jewish state can be a model in the area of implementation of the defined phenomenon for the educational systems of other countries. At the same time, we summarize the most important research surveys dealing with the teaching of the Shoah in Israel. In the area of methods are in more detail introduced "The Survivors' Heritage", "The Historical Approach", "Multi-Level Approach" and “An Interdisciplinary Approach".
\end{abstract}

Keywords: Shoah, Holocaust, Shoah presentation methods, review study, anti-Semitism, Israeli state schools

\section{Introduction}

\subsection{The Israeli Educational System as a Model for the Integration of the Shoah Phenomenon into Teaching}

The main author of the paper underwent a one-month research fellowship at Bar-Ilan University in Ramat Gan. Among other things, the internship was an introduction to the implementation of the Shoah theme in the educational system of Israel as a country that could be a model for other countries in this area. We realize that it is not possible to compare the different historical and social contexts of the existence of Israel and other countries, however, the integration of the defined phenomenon into the education system in Israel can be seen as an inspiration in the application of certain effective practices or methods of implementing the phenomenon of the Shoah (see Terminological Anchoring) in teaching. Especially for this reason the paper deals with possible methods of presenting a defined phenomenon to pupils and students at various levels of institutional education based on the opinions of experts working in some way at educational institutions primarily in Israel. We believe that choosing the appropriate way of presenting the issue to pupils and students represents the most difficult and at the same time the most important stage of the presentation itself to a great extent the abstract events of the Shoah.

\subsection{The Importance of the Shoah for Contemporary Society}

The issue of the Shoah is a warning to contemporary society in the field of protection of democratic principles, moral and ethical values, the formation of an axiological system, and the like. Abrams (2017, p. not specified) claim that the defined phenomenon can be seen as a warning "who is 'different' - whether black or white, Jew or Arab, Christian or Moslem - everyone whose orientation differs politically, philosophically, sexually". Jacoby (2017, p. not specified) compares Nazi Germany's practices with recent events in Rwanda, Cambodia or Bosnia: "Accounts of 
what was done in Treblinka did not prevent mass-murder in Cambodia or Bosnia or Rwanda". Gasanabo, Mutanguha \& Mpayimana (2016, p. 329) to the genocidal manifestations in Rwanda point out: "Rwanda's efforts to develop educational curricula about the Genocide against Tutsi require it to not only grapple with history, but also to draw lessons from elsewhere, especially the Holocaust. Rwandan education, formal and informal, has developed with a new generation of learners to study the genocide. Drawing on lessons from the Holocaust and the Genocide against the Tutsi, educational programs, both in and out of school of it, are guiding learners through encounter with these historical events, helping them to think critically".

The increase in anti-Jewish sentiment in European society can be evidenced by research Antisemitic Violence in Europe, 2005-2015. Exposure and Perpetrators in France, UK, Germany, Sweden, Norway, Denmark and Russia (Due Enstad, 2017), which examined the development of anti-Jewish sentiment in seven selected European countries. A total of 16500 respondents took part in the survey and defined themselves as Jews. A total of $85 \%$ of respondents stated that they perceive the rise of anti-Semitism as a serious problem (Mašát, 2019b).

The importance of the events of one line of the Second World War is evidenced by the fact that the Parliament of the Czech Republic (see https://www.psp.cz/sqw/hp.sqw?akk=7) recently adopted a definition of anti-Semitism, based on International Alliance for Holocaust Remembrance: "Antisemitism is a certain perception of Jews, which may be expressed as hatred toward Jews. Rhetorical and physical manifestations of antisemitism are directed toward Jewish or non-Jewish individuals and/or their property, toward Jewish community institutions and religious facilities" (IHRA, 2016).

\subsection{Terminological Anchoring}

Mémorial de la Shoah (2017, p. not specified) on website states that 'Shoah is the Hebrew word for 'catastrophe'. This term specifically means the killing of nearly 6 million Jews in Europe by Nazi Germany and its collaborators during the Second World War. The English-speaking countries more commonly use the word Holocaust, which is Greek for 'sacrifice by fire'".

Elie Wiesel is considered the first to use the term Shoah. At the same time, the author himself draws attention to excessive profanity of the defined term: "I wrote an essay on Acad, Isaac's sacrifice; the word 'ola'- translated as 'fire victim' or 'holocaust' - struck me. Is it because it evokes the idea of destruction by fire and the sacred and mystical aspect of sacrifice? As a result, the word has become too popular and is used wisely. We use it to describe any event. Its generalization is misguided. Indeed, I have said it again and again, there is no word to describe the indescribable. 'Shoah?' This biblical name adopted in Israel seems equally disproportionate to me. It is used in the sense of an accident, a natural disaster affecting the community: at least they have been in official speeches as well as in the press since the persecution of Jews in Nazi Europe and long before the adoption of the Final Solution. Because the word that describes the pogrom cannot be enough for Auschwitz. After liberation, those who spoke and survived Yiddish simply said 'war' or 'Churban', which means destruction and reminds us of plundering the first and second Jerusalem temples. But the more I go on in my quest, the more I believe that no word is strong and true enough to speak of Treblinka" (Wiesel, 2007, pp. 25-26).

Wiesel's statement on the indescribability of the Shoah-connotation events is associated with Tinberg's (2005, p. 79) mention: "Telling the story of the Shoah, for Wiesel, demands an imaginative recasting of language, a redeeming of words".

In a considerable number of cases, the term Shoah is synonymously confused with the term Holocaust (Mašát, 2017; 2018; 2019a; 2019b; Mašát \& Sladová, 2019; Mašát \& Šmakalová, 2019).

Leonard Grech (2000, p. 8) defines the term Holocaust based on postulation by experts at the conference Teaching about the Holocaust, which held from 1 to 6 April 2000 in the capital of Lithuania: "Holocaust, which is derived from 'holos' meaning 'whole' and 'kautos' meaning 'burnt'. Holocaust means large sale destruction especially by fire. Usually the term is used to refer to the extermination of Jewish communities by the Nazi regime. Sometimes the Hebrew word 'Shoah' is used instead. There are those, however, who prefer to give a wider meaning to the term 'Holocaust', referring not only to the extermination of six million Jews, but also to many other groups including Gypsies, homosexuals, handicapped persons, Jehovah's Witnesses as well as others killed by the Nazis".

United States Holocaust Memorial Museum (in Lindquist, 2013, p. 33) defines the Holocaust at the level of reference to the real impact of events that connects to a given term: "The Holocaust refers to a specific genocidal event in twentieth-century history: the state-sponsored, systematic persecution and annihilation of European Jewry by Nazi Germany and its collaborators between 1933 and 1945. Jews were the primarily victims - 6 million were murdered; Gypsies, the handicapped, and Poles were also targeted for destruction or decimation for racial, ethnic, or national 
reasons. Millions more, including homosexuals, Jehovah's Witnesses, Soviet prisoners of war, and political dissidents, also suffered grievous oppression and death under Nazi tyranny” (Mašát, 2018; 2019b).

In the article we understand the term Shoah to experience one line of World War II from the perspective of Jews (Mašát, 2017; 2018; 2019a; 2019b; Mašát \& Sladová, 2019; Mašát \& Šmakalová, 2019).

The terms Shoah and Holocaust are closely related to the terms anti-Semitism, racism and xenophobia. The term "anti-Semitism introduced the circle of Berlin journalists, headed by Wilhelm Marr, in the summer of 1879. The term quickly expanded to include in the vocabulary of fighters against the alleged Jewish power to which (not for the first and last!) and cultural areas. The newly invented term signaled the break-up of modern hatred with traditional religious forms of anti-Jewish hatred and persecution. At the same time, the said neologism (...) enveloped who was the object of hate" (Kryl et al., 2011, p. 43).

Given the connotation with the genesis of modern anti-Semitism, Breitfelder (2019, p. 118) notes: "Modern anti-Semitism at the turn of the 19th and 20th centuries include virtually all negative relations with Jews - from cautious distance to fanatical hatred. The word invented by Wilhelm Marr has entered the general language and unites the centuries-old negative relationship with Jews: hatred, hostility and persecution".

As to the beginnings of demonization of the Jews as the beginning of anti-Semitic thinking, Bauer (2009, p. 56) states: "We find the beginnings of demonization in the clash of Christians with Jews, which initially began as a family dispute between Jewish sects. As soon as the pagan-Christian group split from the original Jewish faith, there was a need to show the differences between the two theologies. In the early centuries of Christian era, these differences crystallized from hostility and mutual satanization. Both sides considered only one interpretation of God's will legitimate, and the Christian ideology, recognized by state power since the fourth century, had to show that the Jews had a covenant with the devil - if they had not, the pagans who decided to adopt monotheism would resort to Jewish sources rather than their Christian imitation. (...) Which logically implied that the Jews wanted to gain world domination for Satan. The Nazis' anti-Semitism adopted an anti-Semitic image of the Jews and rejected Christian theology; in fact, he embraced Christian anti-Semitism without Christianity, which - quite rightly - he considered a Jewish invention. In this respect, as in several other aspects of his ideology, national socialism drew on the Enlightenment and the French Revolution. After all, Christianity was rejected by François Marie Voltaire, seeing in him the disintegration force he introduced to Europe by Judaism and the Jews whom he despised".

Peroutková (2016, p. 64) notes that "anti-Semitism is a part of history and culture and has been hidden and openly depending on time and social conditions".

United States Holocaust Memorial Museum on its website summarizes the positives that pupils present about the Shoah (see https://www.ushmm.org/ in Mašát, 2019b):

1) "democratic institutions and values are not automatically sustained, but need to be appreciated, nurtured, and protected";

2) "silence and indifference to the suffering of others, or to the infringement of civil rights in any societies, can-however unintentionally-perpetuate these problems";

3) "the Holocaust was not an accident in history; it occurred because individuals, organizations, and governments made choices that not only legalized discrimination but also allowed prejudice, hatred, and ultimately mass murder to occur";

4) "the Holocaust was a watershed event, not only in the 20th century but also in the entire course of human history".

Moisan, Hirsch \& Audet (2015, p. 250) also give reasons for presenting the Shoah issue to pupils and students: "Reason given for teaching the Holocaust is to educate students about 'good'citizenship (...). One of the preferred ways to develop positive moral values is to make links between the Holocaust and current examples of racism and discrimination".

Bauer (2009, p. 57) states that "the anti-Semitism of the Nazis can be seen as a prime stimulus and acceptance of racist ideology as a logical continuation".

Kryl et al. (2011, p. 24) states that "the term racism has only been known since the 1930s. It was first used by Magnus Hirschfeld in the title of his book, published in 1933/1934 in Germany, in which he presents views and ideas about races known since the late 19th century".

"The word race - in the sense of humans - first appeared probably in 17th century Italy (razza) and - denoted creatures or persons of unknown origin. Very quickly penetrated the franchise (race) and from there it was taken into 
German (Rasse). Already French encyclopaedists used this term to denote different human cultures. At the same time, it also served to classify nations according to their civilization level. However, it was very quickly used to denote the combination of religious, civilization, intellectual and physical characteristics of certain ethnic groups. At the beginning of the 18th century, the division of humanity into different races of different value began. At the height of the slave trade, assigning to the lower race provided a rational justification for the very existence of slavery" (Breitfelder, 2019, p. 114, marked by the author of the citation).

On the increasing rate of xenophobic manifestations, Mason-Bish \& Trickett (2019, p. 241) state: "This comes at a time when the terms refugee, asylum seeker and migrants have become merged and political and media rhetoric has depicted those affected as 'other' and unwanted (...). As a result, we have seen a growth in human rights abuses as in Russia whilst elsewhere supposedly liberal countries disengaging with human rights laws and international treaties as agreements as shown in Brexit and debate around scrapping the Human Rights Act in the UK leading to substantial hate crime rises. This is part of a global rise in populist politics and right-wing politics including an increase in the far-right movement feeding xenophobia through a distrust of migrant and refugees. Alongside this there have been steep rises in Islamophobia fuelled in large part by ideology and political developments including Trump's Muslim Ban".

\subsection{Survey of Selected Researches on Ways of Teaching the Shoah}

Most experts dealing with the phenomenon of the Shoah in the context of education direct their research in the field to appropriate methods of presenting the Shoah or Holocaust events to pupils and students. Educator-oriented researchers focus primarily on History teachers. This situation is quite understandable.

Drahi was dealt in her work L'expérience de l'enseignement de la Shoah en France par des professeurs de collège et de lycée: un analyseur de l'expertise professionnelle face à une question socialement vive (2015) with the experience of secondary school teachers in France with Holocaust learning. The research with 30 respondents was conducted through semi-structured interviews. The main objective was to find out how teachers perceive teaching the subject with all its difficulties in connotation with the issue of anti-Semitism, personal experiences of teachers or with preconceptions of students.

In the paper Teaching the Shoah: Four Approaches That Draw Students In (2007), Martin defines four basic methods of working with the topic of the Shoah, which should make pupils and students accessible in a certain way.

Moisan, Hirsch \& Audet, in the paper Holocaust Education in Quebec: Teache"s Positioning and Practices (2015), provide a list of methods in which students in a Canadian city are acquainted with a specific topic.

In the article Taking (and Teaching) the Shoah Personally (2005), Tinberg gives a detailed account of the possibilities of memoir and autobiographical literature for presenting one line of World War II to pupils and students through literature. The author bases his arguments on the work of Art Spiegelman Complete Maus $(1986 ; 1991 ; 1994)$.

Tinberg \& Weisberger in their publication Teaching, Learning and the Holocaust. An Integrative Approach (2014) are dedicated to presenting the Holocaust through historical facts and literary texts. The authors apply methods and procedures postulated by the Scholarship of Teaching and Learning. They have a discussion with the students who have passed the course and with the teachers who coordinated the lessons. Based on the interviews, they then streamline the application of the approach and adapt it to current educational requirements.

Jennings in the article Holocaust Education and Critical Citizenship in an American Fifth Grade: Expanding Repertoires of Meanings, Language and Action (2015) presents the results of an experiment in which fifth grade pupils were educated year-round in the areas of rights, mutual respect (tolerance) and responsibility through holocaust literature. In this education, children sought to understand the social, political, and moral consequences of the Holocaust. The experience that children have gained through the educational process leads pupils to engage in social participation.

Nowel \& Poindexter (2018, p. 285) undertook a qualitative research survey among 16 teachers of social studies in their personal growth in question as social justice educators: "In this qualitative teacher research study we attempt to answer these questions by analyzing the coursework and reflections of 16 social studies preservice teachers (PSTs) as they completed an in-depth study of the Holocaust through historical research, field trips, and reading young adult literature, and designed creative and engaging lessons to teach the Holocaust to secondary social studies students (grades 6-12)". The basic research finding was to find some gaps in the range of knowledge of future teachers in the field of historical events and at the same time some inability to link these historical events with their own (real) life. 


\section{Anchoring the Terms Shoah and Holocaust in Educational Curricula of Selected Countries}

We do not consider synonymizing the naming of specific aspects of World War II (see Terminological Anchoring) as an insufficient prerequisite for the implementation of these events in the curriculum or for their curriculum anchoring: we consider it important to indicate the focus of the issue (Mašát, 2018). To the given notes Carrier et al. (2015a, p. 5): "It is generally referred to as the 'Holocaust', while fewer curricula use the term 'Shoah', or else both terms in conjunction. In some cases, curricula forego both the terms 'Holocaust' and 'Shoah', describing the event. With alternative terms such as 'extermination' or 'genocide of the Jews', with indirect references to the event (with terms such as 'concentration camp' or 'Final Solution')". Carrier et al. (2015a, p. 38) observes: "The Holocaust is part of the curriculum in approximately half of the countries investigated, with contexts and terminologies varying. The Holocaust is located most frequently in history curricula in the context of the Second War War, but features in repeated instances in the context of the issue of 'human rights' or 'human rights violations', thus forming part of teaching in social studies or, more rarely, ethics education or philosophy. The event referred to primarily using the term 'Holocaust', with isolated preferences of the term 'Shoah' or use of both terms side by side. In several instances, nether 'Holocaust' nor 'Shoah' find use; instead, an unambiguous description of the event appears, using alternative terms such as 'extermination' or 'genocide of the Jews'".

Carrier's interpretation can be supplemented by the statement of Acedo (2010, p. 2): "Speakers of French, German and Hebrew prefer to use the term 'Shoah', which means catastrophe in Hebrew. Others prefer the use of 'Churban', meaning also catastrophe in Yiddish". Differences can also be seen in the line of explicit naming of the victims of these phenomena.

- The first group - direct reference - includes educational curricula of countries in which we find the word Holocaust or Shoah, or explicit alternative naming of these events (such as Albania, Ethiopia, and Poland). A mixed model (i.e. the use of both terms) can be found, for example, in Germany (Saxony) or Switzerland. Alternative names, for example, in Namibia, Germany (Lower Saxony) and Belgium (Carrier et al. 2015b, p. 69).

- The partial references can be characterized by the situation "when the Holocaust named in the curriculum as a means to other ends, the historical meaning and complexity of the event are not addressed" (Carrier et al. 2015a, p. 5). Countries that have a Holocaust / Shoah curriculum anchored in this way include, for example, Slovenia or Belize.

- The third group of references is to recall the mentioned terms only within the context - the context only - and is found in the curricula that mention the hardships of World War II in a broader context. These include, for example, Kenya, Norway or Rwanda (Carrier et al. 2015a, p. 5).

- The last model includes countries that have no deadlines in their curriculum documents - no reference. These are the countries whose curriculum "do not stipulate the specific contents of history teaching" (Carrier et al. 2015a, p. 6).

It is worth noting that considerable differences can be observed in the field of integration of the subject in question between schools located in Western Europe and the countries of the former Soviet Union. In schools that were under the influence of the Soviet Union until the beginning of the 1990s, the issue of the Shoah with all its connotations is "largely ignored or underplayed" (Carrier et al., 2015a, p. 168). Differences can also be traced between schools within Israel, between private, state and Jewish educational institutions.

\subsection{Israel's New Educational Curriculum in the Context of the Shoah}

Dror (2001, p. 29) remarks on the Israeli curriculum in the context of the Shoah: "[Analyse] the complex relations between the Israeli (Jewish) society and its educational frameworks, in comparison to some of the studies on the impact of the Holocaust on Israel. The article discusses eight findings, which raise controversial moral questions about the way in which the Holocaust is taught in Israel. These include, for example, the contentions that Holocaust curricula stimulate deep emotions, without enough balance being given to the cognitive and emotional aspects of learning, and that Holocaust studies are compulsory, while other important parts of the Jewish heritage remain unknown to the majority of non-religious students".

Gross (2010) concludes that Holocaust education as a primary component of Jewish identity has not been systematically conceptualized in the state education system in Israel, even though "in 2013, the then Israeli Minister of education Rabbi Shai Piron approached the International School for Holocaust Studies (ISHS) at Yad Vashem requesting the development of cross-grade, tailored educational curriculum" (Kaminka, 2016, p. 238).

ISHS dealt with three key dilemmas in the field of Holocaust teaching:

- "What to teach? 
- How can it be taught?

-At what age must one begin dealing with the Holocaust?"

Israeli curriculum documents for all levels of education have changed the application of the Shoah theme. The transformation was reflected in a new approach in the field of implementation of the defined topics into the curriculum. The Ministry of Education of Israel, the Israeli Museum Yad Vashem and other Shoah legacy institutions cooperated on curricular changes. "The new curriculum includes Shoah education units designed for kindergarten, elementary school, junior high school and high school, with between 2 and $15 \mathrm{~h}$ of Shoah education per year, depending on the age group" (Cohen, 2016, pp. 183-184).

In the article Teaching the Shoah in History Classes in Israel High Schools (2009), Gil discusses the Holocaust in Israel following the adoption of the new Israeli curriculum in 2000. He analyzes teaching through official and unofficial textbooks or examinations in various subjects in four areas:

(1) Essential topics in the curriculum before adopting a new education policy in Israel;

(2) new topics that have been implemented in the curriculum after 2000;

(3) integration of history into the new concept of Israeli education, with a focus on the history of

(4) academic process skills.

A similar issue is presented by Porat (2004, p. 620), which showed "that the selection of information, its ordering and the moral lessons associated with it form a particular historical perspective - one shaped oriented in relation to the political and social arena". Based on this criterion is sought in "deliberations of official in the Ministry of Education and discussion of political figures that influenced the Ministry's educational policy". Resnik (2003, p. 309) in the area of "ceremonies and extracurricular social activities" integrated into teaching in Israeli schools include, for example:

- "The Holocaust and Heroism Remembrance Day ceremony";

- "visits to Holocaust commemorative institutions" or

- "youth delegations to Poland".

Cohen presents the results of a mixed design research that examined the effectiveness of the application of the new Israeli educational curriculum in educational reality in a contribution Teacher autonomy within a flexible national curriculum: development of Shoah (holocaust) education in Israeli state schools (2016) The qualitative part of the research was conducted through interviews with 47 experts in the field of the Shoah, and the quantitative part of the research was conducted through questionnaires intended for students, teachers and heads of Israeli state schools. A total of 307 directors, 519 teachers and 2540 students completed the questionnaire. The evaluation of both phases revealed some discrepancies between the theoretical anchoring of the Shoah issue in the educational curriculum and the educational reality, for example because of the fact that there is no unified 'collective memory' of Shoah among Israelis (Cohen, 2016, p. 185), on which the new curriculum was built to some extent.

On the concept of Israeli collective memory based on the Shoah event, Friedländer (1990, p. 5) states: "It has been argued that after a period of 'confrontation' with the traditional symbolic world of Judaism, during Israel's first years of statehood in which the Shoah was of minor importance, a second period started, in the late 1950s, witnessing the stage-by-stage creation of a 'civil religion', of which the Shoah became one of the central mythical components. However, there does not seem to have been such a clear-cut division between the two epochs, at least concerning the Shoah. From the late 1940s on, systematic attempts were made to insert the Shoah within a major traditional framework of interpretation, carrying new significance as a result of the creation of the state".

\subsection{Teaching the Shoah on Israeli Public Schools in the Context of the Curriculum}

We analyzed the content of the Israeli curriculum in public schools ("junior high school" and "high school"). We consider important to note that we know the implementation of deadlines within Israel is, in a positive sense, borderline. Friendländer (1990, 2013, p. 5), in the connotation with our statement, notes: "The major increase of in references to the holocaust from the late 1960s, on in the Jewish world and elsewhere, is a matter of common knowledge and massive evidence. Yet no enduring, compelling narrative of mythical dimensions seems to have emerged. This is particularly notable when one considers the Israeli attempts to establish an an official representation of the historical significance of the Shoah or when one refers to the evolution of the same issue among American Jews and on the Western scene at large, as a result of the impact of the culture industry".

On a complex scale, the situation regarding the presentation of the phenomenon of the Shoah is very complicated; 
Kaminka, current museum director Yad Vashem, in his article Teaching about the Holocaust in Israel: A Pedagogical Approach Adopted by the Israeli Ministry of Education (2016) stresses the importance of a careful approach to the issue, taking into account the cultural sensitivity of the target audience, the history of the country and the current trends in the educational process: "In Israel, where Holocaust education has been created and developer over decades to produce models used around the world, this approach can be examined using the prism of the nationally instituted curriculum" (Kaminka, 2016, p. 237). Kaminka postulates the idea that teaching about the Holocaust should not be "focuses not only on the Holocaust as a historical event but also as a human story". Based on his statement, Kaminka postulates three basic areas that should be introduced to pupils and students:

1) "Questions regarding the lives of the Jewish victims before and during the Holocaust";

2) "Questions regarding the bystanders and the 'Righteous among the Nations'";

3) "Questions regarding the Perpetrators" (Kaminka, 2016, pp. 238-239).

The need for a multiraterial view of the Holocaust is illustrated by Resnik (2003, p. 306): "The study of the Holocaust intended to link the student with the Holocaust experience as another means, among others (religious, folklore, for instance), to promote the unity of the Jewish people". Collective identity construct is related to the thesis posed by Julia Resnik. Krejsová $(2017$, p. 10) defines a circumscribed term as "the resultant of interactions through which similarities with 'our' group and differences with, 'their' group are created".

Cohen $(2016$, p. 167) in a paper devoted to the development of the Shoah education in Israeli public schools, publishes the results of his research into the readiness of teachers to teach the subject matter in the light of the ongoing discussion (not only) on anchoring defined terms curricula of certain levels of education in Israel.

In the introduction, Cohen emphasizes that "the Shoah (Holocaust) is inherently a difficult, sensitive and complex subject to address in schools. How this subject is (or isn't) addressed in various times, places and school systems is linked to many demographic, political, social and pedagogic factors" (Cohen, 2016, p. 167). We find a consensus in the opinion of Kaminka and Cohen in the area of social anchoring of the given topic and the difficulty of grasping the defined issues within the educational process. Cohen (2016, p. 168) states: "Pedagogy of the Shoah is an emergent phenomenon, address the issue, for example, through textbooks, curricula, museums, memorials, films, literature and more". According to Cohen (2016, p. 167), the subject provides scope for more generalized discussions, such as anti-Semitism, generally human values, minority rights or political power.

In Israeli state schools, students encounter the Shoah theme several times in the educational process, both in formal (school) and informal (extracurricular) activities (Cohen, 2016, p. 169). Kaminka (2016, p. 237) on the integration of the concept of the Shoah into the Israeli curriculum in formal activities notes: "The Holocaust is being taught in the formal education systems in many countries around the world and is subject to extensive research. (...) In Israel, the subject matter of the Holocaust remains central within the education system, both in historical teaching in high schools, as well as in a meaningful capacity surrounding 'Yom HaShoah', the Holocaust and Heroism Remembrance Day held annually".

Cohen (2016) also found that the subject matter was inherently more important to the Jews when evaluating the research, mainly due to some degree of stigmatization of the Jewish people in cooperation with an effort to understand these events. The research results also offered comparisons between junior high schools' students and elementary schools' students. "Shoah education became well established in junior high schools. Elementary school students and even kindergarteners are introduced to the issue though ceremonies on the national Shoah Memorial Day" (Cohen, 2016, p. 174, taken from Brody, 2009, p. 10).

The research brings remarkable results in the area of the hour of the Shoah. The issue was discussed with directors of Israeli public schools in an interview. The number of hours spent on Shoah at junior high school and high school ranged from 130 to 150 hours per year (both school and extracurricular activities). As expected, the topic is most often applied in History teaching, but it is also implemented in Literary Education, Civics, Religion and other fields of education. A total of $72 \%$ of Israeli public school headteachers and $79 \%$ of teachers from the same institutions believe that the teaching hours devoted to the Shoah theme should be increased. Total $83 \%$ of students of the same form of institutional education share the same opinion. In his research, Cohen also investigated the educational areas in which the Shoah issue was implemented in the curriculum of Israeli public schools: "Aside from the obligatory History lessons, the subject may be addressed in classed such as Literature, Citizenship, Religious Studies and more. There are also many information activities such as field trips and memorial ceremonies" (Cohen, 2016, p. 175).

Cohen (2016, p. 185) states at the end of the paper: "The vagueness of the Ministry of Education policy has been perceived as a weakness which needs to be corrected. This is part of the motivation behind the new standardized 
curriculum. However, I would argue that it is precisely the lack of clear definition that enabled and continue to enable educators to individualize the curriculum. The approach of gradually expanding the scope of a subject while leaving some aspects of curriculum implementation flexible may be considered in light of Shoah education in other settings, as well as in regard to other subject matters. This may be particularly helpful for teachres working with multi-ethnic student populations with divergent 'memory cultures' and perspectives on issues related to national and international history".

The results presented by Cohen's research demonstrate the fact that Israeli education is built on the events of the Shoah. On this point, points out Resnik (2003, p. 297): "The Holocaust has become the central event of Jewish history defining Israeli identity". This fact is not surprising given the historical facts under which the State of Israel originated (compare Krupp, 2013).

Events that can be collectively called the Shoah in a way substitute for a certain lack of a united national feeling of the people of Israel (for example, in the Czech Republic it is an area of common history or in most cases the same mother tongue). This can be illustrated, for example, by the fact that the people of Israel do not perceive themselves as Israelis, residents of the State of Israel, but as Jews: followers of Judaism or residents of the Jewish state.

Brazzo \& Schwarz (2010) emphasize the importance of not only perceiving Jews who survived the extermination of the Nazi machinery in the reception of the evolution of the self-concept of Israel's inhabitants, but also of the fate of Jews who emigrated to Palestine before the persecuting persecution practices of Nazi Germany.

\section{The Place of the Shoah Theme in Literary Education}

Literature in the presentation of the Shoah theme offers considerable potential. According to Jordan (2004, pp. 199-200) is literature "one of the best pedagogical tools for educating youngsters about the facts of the Holocaust, for conveying the importance of remembering what happened without explicitly divulging emotionally disturbing information”. Oliveira (2017, p. 1164): notes that “„Literature is a way of postulating reality, of inventing possible other modes of thinking and inhabiting the world".

Acedo (2010, p. 1) emphasizes the integration of the Holocaust (Shoah) into teaching, given its potential in the protection of human rights and freedoms and the like: "Holocaust education is often justified not on the basis of its historical significance, but as a way to guide individual and collective conduct in order to oppose bigotry in the present and future. Holocaust education can make a great contribution if its lessons help to protect human rights, and if they counteract hostility and discrimination along such too-common demarcations as class, disability, ethnicity, faith, gender, and sexual orientation".

At present, there is a considerable amount of intentional literature with a defined phenomenon. Yudkin (in Abramovich, 2019, p. 9) characterizes Holocaust literature as literature that "is writing that takes its subject and starting point from the war conducted against the Jews from 1933 to 1945. Although that is the point of origin, the continuation is less certain, less defined and less crystalized. The effects go on, and writing allows these to move in different directions. The writer as narrator may be the prime focus of the narrative or a reporter of a distant event. Such an account may be a chronicle in which the chronicler is the principal actor or a subsidiary actor. Or he may not be involved in the story at all".

Using literary texts to acquaint pupils with a given historical reality implies the need to eliminate or degrade some aspects of the phenomenon, because of the effective use of literature as a means of presenting the Shoah events. On this point, observes Lindquist (2008, p. 28): "The content decision-making process involved in developing Holocaust curricula is unusually complex and problematic. Educators must consider factors such as historical accuracy, selection of topics covered, potential teaching materials (such as textbooks and literary texts), and graphic materials (such as films and photographs) as they plan their Holocaust units. Judiciously considered decisions regarding these factors allow teachers to present accurate, appropriate, and meaningful units on the subject, thus conveying the story of the Holocaust in ways that are pedagogically sound and historically viable. Accordingly, the author does not focus on the content to be included in a Holocaust unit but rather considers several factors important to selecting that content".

At present, there is a significant development of literary production in the field of intentional Shoah literature. Teachers who include the Shoah issue in Literary Education should be consistent critics of artistic narrations because „many works contain peritexts informing young readers how much of the text is based on evidence and how much on conjecture or imagination, thereby blending traditional history writing with fiction. Such trends are not surprising: teachers are encouraged to use Holocaust literature to complement history teaching" (Kokkola, 2003, pp. 2-3). 
Objective reception and subsequent reflection of texts can lead to the selection of appropriate literature."Holocaust literature for young people attempts to weave together a variety of different textual traditions - for writing history generally, for writing specifically about the Holocaust, for writing for young readers, and for portraying human lives..." (Kokkola, 2003, p. 9).

In our opinion, the Shoah issue can also be used to present the importance of democracy, highlighting the aspects that lead to the maintenance of this political system. Last but not least, the literary elaborated topic of the Shoah can be used as a means to acquaint pupils with a certain historical period. Jindráček (2011) concluded in his research that activities that enrich Literary Education with a historical and cultural context are among the most popular activities of pupils. Jordan (2004, p. 216) observes: "In a teaching complex and controversial subject such as the Holocaust, which is both emotionally and intellectually difficult to understand, few tools are as useful or as illustrative as a good work of literature. Holocaust literature written specifically for children is in genre which there are literally thousands of titles from which to choose; however, not all these works are equal in their appropriateness or their effectiveness in teaching children in a sensitive manner".

\section{Methods of Work with the Topic of the Shoah in the Context of Institutional Education}

Every teacher who decides to present the topic of the Shoah to the pupils is faced with a decision on what method to define the phenomenon.

An extensive list of specific methods of Holocaust teaching and practical examples are presented in the paper The pedagogical approach to teaching the Holocaust (Imber, 2013).

A way for teachers to introduce pupils to the phenomenon was suggested by the experts at the seminar Teaching about the Holocaust, which took place in Vilnius, Lithuania in 2000 (a detailed report is available on the website (https://rm.coe.int/1680494240).

In the publication Teaching Literature to Adolescents (2016) the authors give an overview of possible methods of working with literary texts at "middle and high school". "These methods are based on a social constructivist/socio-cultural theory of learning that emphasizes the value of engaging students with alternative perspectives portrayed in literature, perspective-taking that is extended through writing, talk, and drama activities involved in responding to literature" (Beach, Appleman, Fecho \& Simon, 2016, p. 7).

As part of the Anglo-American methodological approach to the issue, the so-called integration approach in the area of mediation of a defined object is currently being developed. According to Tinberg \& Weisberger (2014, pp. 12-13) presentation of the Holocaust issue through an integrative approach "can help to foster not only critical thinking but an appreciation of diversity and a standard of morality among students".

As mentioned above, the teacher must consider a significant number of aspects related to the target group. Lindquist (2010, pp. 79-80) notes that "Holocaust educators must develop strategies that will allow them to overcome institutional and community pressures that may hinder their teaching of the subject, preclude that teaching altogether, or create untenable situations that could cause teachers to endure professional and/or personal dissonance as a result of including Holocaust instruction in their classrooms".

Four possible approaches to alleviating the differences between the pupils' experience and the empiricism presented to them are postulated by Martin (2007, pp. 493-503):

- "Student Presentations on Holocaust Survivors;

- Documentary Film on the Ghettos and the Camps;

- Student Debates: Why Did This Happen?;

- Did the Shoah Really Happen? Evaluating Sources and Evidence".

At the seminar Teaching about the Holocaust (2000) the methods of teaching about the Holocaust were divided into:

- the so-called traditional methods that "would perhaps involve the use of pictures probably found in the textbook that is being used" (Grech, 2000, p. 15) and

- other methods that "often involve the new technology: CD ROMS, the Internet, films and documentaries, and interviews with survivors" (Grech, 2000, p. 15).

The following theses were agreed within the Lithuanian seminar:

- "we need not and should not stick to one method". 
- "Children learn in different ways, hence the necessity to employ various methods of teaching".

- "Teaching has to be transformed into learning. Hence students have to be motivated. Therefore, the necessity to employ challenging and stimulating methods of teaching".

- "If we stick to one method, lessons will become boring".

- "Traditional methods (such as the narrative method) still have an important place in history education. Students can be captivated and motivated by such methods".

- "Teaching aids, whatever they are, can never replace the teacher. But the teacher has to be a professional. Apart from knowing the content, he or she has to be well trained in certain teaching skills".

Among the targeted teaching methods ("certain teaching skills") Grech (2000, p. 15) incudes:

- "ability to be clear with regard to objectives";

- "ability to choose the most appropriate and effective method of teaching, considering the situation";

- "good use of voice";

- "importance of dramatization";

- "ability to put feeling into what is being said and presented";

- "the importance of eye contact";

- "body language";

- "questioning technique".

At the final conference IHRA Education Research Project held in Lucerne in February 2016, two basic goals of the Shoah education were postulated:

(1) "two necessary (but partly conflicting) main goals are commemoration of victims" and

(2) “prevention of 'genocides' implicating conclusions for actual crises like the Syrian civil war and fugitives" (von Borries, 2017, p. 425).

As the most important point in the demarcated field, experts have defined the need for day-to-day education on the issue, but it is necessary "distinguished carefully from intervention by elaborated best-practice teaching" (von Borries, 2017, p. 425).

The main models of acquainting pupils and students with the topic of the Shoah (Holocaust) are defined by Imber (2013, p. not specified): "The Survivors'Heritage", "The Historical Approach", "Multi-Level Approach" and "An Interdisciplinary Approach".

4.1 "The Survivors' Heritage"

"The Survivors' Heritage" is a model without which, according to Imber (2013), the Shoah theme cannot be presented. Authentic testimonies are the most faithful mediator between the historical event and the persons involved. Imber (2013, p. not specified) regarding the approach notes: "Holocaust survivors play a central role in the writing of holocaust history, in the shaping of memory, in memoration and in educational work".

Similarly, Martin (2007, p. 495): formulates the approach "Student Presentations on Holocaust Survivors": "Students use the time to interview the survivor or relatives who knew the survivor better than the student does".

\subsubsection{Diaries of Jewish Children}

Many testimonies arose in the ghettos, which were primarily intended to group people of Jewish nationality in one place. On the role of ghettos in the context of constituting the events that culminated in the Shoah / Holocaust, Ofer (1998, p. 1) states: "Nonetheless, during the long months of ghetto life and through the deportation to the death camps, families and remnants of family units did not cease to exist. Even in the death camps following the separation of the sexes and the killing of virtually all mothers, children and the elderly, inmates clung to what was left: either to a fragment of the family, such as siblings or cousins, or to 'surrogate families' such as friends or landsmen - or, in the absence of all, to memories of the family that once was" (compare Medding, 2011).

Einwohner \& Maher in the article Threat Assessment and Collective-Action Emergence: Death-Camp and Ghetto Resistance during the Holocaust (2011) in the context of social studies, they dealt with the concept of perception and acceptance of threats by people interned in ghettos. We believe that the vision of an indefinite threat (for example, transports to the East) has largely influenced the literary records of internees and adolescents. 
Seeman (2020, p. 205) deals with trauma from internment from a purely psychological point of view: "Learning about the events that took place there over the last 200 years has opened my eyes to aspects of anti-Semitism of which I was not previously aware. I have learned that discrimination and stereotyping, no matter how irrational, rise to the surface in times of tension and adversity. I have learned that anyone can become an anti-Semite, discriminating not only against Jews but against people of all Semitic backgrounds, often at the instigation of third parties. I have also learned how trauma is transmitted from generation to generation so that the harms human beings inflict on each other live long after the traumatic events themselves are forgotten".

Literary records of children and adolescents interned in concentration or extermination camps or in ghettos closely correspond to "The Survivors' Heritage" method. Let us assume that the integration of these memories can be very beneficial for the students in the area of the Shoah events, because in most cases the events are viewed through the prism of their peers. At the same time, this approach corresponds to the thesis that the phenomenon of the Shoah should be presented to pupils and students through the individual's life destiny, which may lead to a certain disappointment of the subject.

We believe that it is the age specificity that can attract elementary school pupils, it can be used as a motivational impetus, the way of bringing certain events to the focus of adolescents during the war years could be closer to teenagers in the 21 st century. Finally, we are of the opinion that the non-pathetic tone of the records of everyday events in selected diaries, often accompanied by observations about adolescents' concerns and joy, will increase pupils' motivation to read literature on the subject.

Jordan (2004, p. 201) states: "Perhaps the easiest way for today's children to identify with children of the past is through self-narrated stories of Holocaust-era children. (...) When they identify with the protagonists of the books they read, history - the Holocaust - becomes highly personalized".

Literally elaborated memories of World War II reflecting the fate of the Jewish population are important to the recipients on several levels. They provide an authentic period record that can be viewed historically as evidence of persecution of Jews. Malý (2016, p. 164) states in connotation with our assertion that "diaries then, given that memory, and especially the literary one, is very unreliable, can serve as the only truly relevant authentic literary document". We are aware that the chosen issue cannot be viewed in a simplified way, when familiarizing pupils with the diary records of Jewish children from the Second World War, we must remember that the child, as an author, writes texts that are specific in that penetrates the adult world (Zajac, 1989 in Urbanová, 2018). For this reason, we must select the demonstrations very carefully and consider several specific psychosocial, historical, cultural and other aspects. We must also be aware that the creation of a diary was often motivated by the necessary escape from reality associated with the "catharsis effect" (Urbanová, 2018, p. 269).

These aspects influenced the authors of the diaries and in a way contributed to their creation, we should be aware that "the creation of Jewish children is different in its starting strategy from that for children" (Urbanová, 2018, p. 257). Lederbuchová (2010, p. 57) comments on child reading strategies: "A child reads the text always adequately to its reading needs, attitude and competence, with a natural and understandable risk of misunderstanding the meaning of the text according to the author's semantic gesture".

Some limits of the approach can be expressed through Caroll's words (1999, p. 68): "As there is no merit to having survived, Levi also claims that there is also no merit in testifying to what was experienced in the camps. (...) As there is shame in survival because survivors feel less worthy than others who died, there is also shame in testifying because all testimony is also unworthy". So, if we generalize Carroll's words, the thing is that survivors of the Nazi extermination machinery do not want to testify because of their belief in their inferiority, mainly because they feel incomplete because of their survival, that is, they did not know the "complete" Nazi tyranny. It closely corresponds with the survivor's testimony.

\section{2 "The Historical Approach"}

"The Historical Approach", in whose center stands "reflecting upon the Holocaust from a historical perspective also encourages students to think historically..." (Mosian, Hirsch \& Audet, 2018, p. 252), it uses the historical context in presenting one line of events of World War II. This procedure "should lead to substantive study of the subject (...) and include historical context as well as reflection on democracy and totalitarianism, on Nazi ideology and propaganda, on social conformity, on international relations, on opposition groups and their actions, and on the victims as actors".

Using literary texts to acquaint pupils with a given historical reality implies the need to eliminate or degrade some aspects of the phenomenon, because of the effective use of literature as a means of presenting the Shoah events. 
Lindquist (2008, p. 28) points out: "The content decision-making process involved in developing Holocaust curricula is unusually complex and problematic. Educators must consider factors such as historical accuracy, selection of topics covered, potential teaching materials (such as textbooks and literary texts), and graphic materials (such as films and photographs) as they plan their Holocaust units. Judiciously considered decisions regarding these factors allow teachers to present accurate, appropriate, and meaningful units on the subject, thus conveying the story of the Holocaust in ways that are pedagogically sound and historically viable. Accordingly, the author does not focus on the content to be included in a Holocaust unit but rather considers several factors important to selecting that content". According to Hník (2012, p. 143), working with non-literary aspects of the work is valuable because it can "enrich the understanding of the text with extra-literary contexts: period, thought, biographical". At this point, therefore, the Shoah texts seem to be a suitable means of acquainting pupils with one line of the events of World War II from a historical perspective.

\section{3 "Multi-Level Approach"}

"Multi-Level Approach" is based on the premise that "the inculcation of ethical values must begin at a very young age" (Imber, 2013, p. not specified). Part of the research, which dealt with the opinions of Czech Language and Literature (native tongue) teachers on the implication of the topic of the Shoah in the teaching of Literary Education, was also the question of when pupils should first get acquainted with the Shoah (see, for example, Mašát, 2018; $2019 \mathrm{~b} ; 2019 \mathrm{c}$ ). A total of $48.8 \%$ of the survey respondents answered that the ninth year is ideal for introducing pupils to the topic (this is related to the curricular anchoring of "World War II" in the Czech normative curriculum document this year); no one chose the kindergarten option - the main reason was the certain nature of the Shoah events. These answers are quite interesting in the context of the Israeli curriculum, which prescribes certain presentation of the selected phenomenon to children in kindergartens (for the integration of the Shoah phenomenon into kindergartens in Israel see Ziv, Golden \& Goldberg, 2015). This approach is also related to Multicultural Education, which appears to be closely linked to the issues raised by the Shoah issue (minority rights, perception of difference as a positive social aspect, delimitation against xenophobia and the like).

Mosian, Hirsch \& Audet (2018, p. 252) define "The Ethical Approach", which should "leads students to answer questions such as 'what where the moral and ethical dilemmas of the different players in this context?' This kind of teaching is intended to prompt reflection on values an issues such as tolerance, freedom, social order and conformity, justice, the ambivalence of humankind..." .

With the ethical aspects of the Shoah connotate "The Human Rights Education". This approach looks at the issue through "power, rights and legislation, as well as human dignity. Relationship between the state and its citizens are central to this angle of study, as is the role of citizens and organizations in safeguarding the rights and the full citizenship of all individuals (...)".

\section{4 "An Interdisciplinary Approach"}

"An Interdisciplinary Approach" based on the assumption that the presentation of the story of a person opens the possibilities of understanding the events of the Shoah from different points of view, which include an understanding of the human being and the human spirit. According to Imber (2013), these metaphysical aspects should also be a part of the teaching of the Shoah. The interdisciplinary approach includes Art, Literature, Philosophy and other disciplines. By combining these disciplines, one can attain an understanding of the human soul, which cannot only be achieved by studying historical documents. We believe that most of the literary relics dealing with the Jewish line of the Second World War and having a certain degree of authenticity combine these aspects and, in our opinion, through reception of these written relics can at least become a holistic knowledge of a person experiencing the suffering of persecution with all its consequences. The "interdisciplinary approach" is closely related to the artistic narratives on the topic of the Shoah and their educational and educational (such as building positive axiological values) potential. Certainly, it is important that the phenomenon of the Shoah is introduced to pupils through multiple educational fields, although history should be the primary subject - given its focus. Above (see part 3), we have tried to partially define what place Literary Education takes in the presentation of the events.

Some correspondence between this Imber postulated approach can be found in the formulation "The Intercultural/Antiracist Approach". "Teachers adopting this approach strive to make their students understand what racism is and in what forms and by which mechanism it is expressed. Thus equipped, students are able to recognize its manifestations and also, ideally, to avoid repeating them".

Based on an interdisciplinary approach to the topic of the Shoah based on artistic narratives, is based the anthology of the Shoah texts The Call of Memory. Learning About the Holocaust Through Narrative (2008a) which is equipped 
with a methodological manual The Call of Memory. Learning About the Holocaust through Narrative. A Teacher's Guide (2008b). These publications deal with the possibilities of presenting the Holocaust theme to pupils of different ages. The methodological guide guides teachers in detail how to work with the selected snippets. This publication focuses on getting to know the Shoah events as such through artistic narratives, while the authors focus on educating themselves about the factual anchoring of aspects of the Shoah events, with an emphasis on the persecution practices of Nazi Germany affecting the everyday life of persons of Jewish nationality. Selected excerpts are categorized into ten sections connotating the experience of one line of the Second World War events from the position of Jews: for example, the sections In the beginning, The Gathering Storm or Under Occupation. The anthology contains excerpts from the following authors: Aharon Appelfeld, Susan Prinz Shear, Albert Harper, Ida Fink, Elie Wiesel, Ilse Aichinger, Bernard Gotfryd, Rachmil Bryks, Isaiah Spiegel, Zofia Nalkowska, Cynthia Ozick, Sara Nomberg -Przytyk, Kurt Vonnegut Jr. and Aharon Meged.

\subsection{Other Possible Approaches: "Documentary Film on the Ghettos and the Camps"}

Martin (2007, p. 496) defines as a special category of methods of presentation of the Shoah theme "Documentary Film on the Ghettos and the Camps". Martin (2007, pp. 496-497) enumerates for example Schindler's List, which "can be used in the classroom to good effect". Mediating events of one World War II line through films / documentaries can be quite interesting for pupils.

Kerner publishes several interesting topics and their possible use in publication Film and the Holocaust. New Perspectives on Dramas, Documentaries, and Experimental Fims (2011).

Holocaust films implicitly intended for children are discussed in Brown's article Not in Kansas Anymore: Holocaust Films for Children (2003).

Listing specific movies categorized by role of characters (for example The Hollywood Version of the Holocaust; The Jew as Child; The Personal Documentary or Documentaries of Return) served in a book called Indelible Shadows. Film and the Holocaust (2002) defines Insdorf.

We believe that the implementation of the Shoah or Holocaust film processing into real teaching is quite demanding, mainly due to lack of time. We are of the opinion that, for example, film clubs in which the work can be viewed without undue interruption represent a more suitable integration space for the audiovisual reception of the Shoah phenomenon. In the research we conducted among Czech Language and Literature teachers, the method of comparing a film or theater performance with a literary model received only $45 \%$ positive answers (i.e. respondents chose "yes" or "rather yes" in terms of using the method). "We believe that the low rate of positive response is mainly due to the considerable time required of the method. In order to achieve the desired effect within this level of comparison, it is necessary for the pupils to watch the film (or theater performance) and read the complete text template (the order of the two components is irrelevant for the purposes of our commentary). In the Czech educational reality, rather than active reading experience in the text, the film or theater version is used rather. This method can act as a special feature, but we believe that in Literary Education there should not be a delay in pupils' active reading experience with text too often" (Mašát, 2019c, p. 279).

4.6 Other Possible Approaches: "Student Debates: Why Did This Happen?” \& Did the Shoah Really Happen? Evaluating Sources and Evidence"

Martin (2007, pp. 499-500) further postulates the approach "Student Debates: Why Did This Happen?" Students should argue properly in the debate. The last Martin postulated approach is "Did the Shoah Really Happen? Evaluating Sources and Evidence", in which students should be confronted with opinions whose center is the information that events connoting one line of events of the Second World War did not happen.

Implicitly, this method is directed against the views of Holocaust deniers who claim that these phenomena are due to the conspiracy of world Jewry. "Their aim is to get as much audience as possible for their ideas to present their scientific evidence, twisted historical facts, and thus help to uncover the world lie about the Holocaust. Unfortunately, the ancient tendency to seek a Jewish conspiracy for the problems of the country is still deeply rooted in society" (Ševčíková, 2013, p. 182).

Kryl et al. (2011, p. 237) adds that "Holocaust deniers are looking for their roots in the opinion environment of a group of historians of the first half of the 20th century who tried to reinterpret the causes and background of World War I and II. In the case of World War II, some of the practices of the allied coalition (bombing Germany or expelling the Germans from liberated territories) and Nazi crimes were equated with Germany. These views spiced up by the Holocaust denial, was shortly after the end of World War II the French fascist Maurice Bardèche (1907-1998)". 
Many world experts postulate different methods of presenting the Shoah theme to younger schoolchildren: "Many teachers hold that the Shoah be taught in the lower grades, arguing that teaching tolerance through Holocaust study is developmentally appropriate in that setting". Given the focus of the paper, we do not consider it necessary to present such oriented opinions (see for example Hersh, 2016; Kraft, 2014 or Unterman, 2016).

\section{Conclusion and Discussion}

The paper dealt with methods of presenting the Shoah theme to pupils and students at various levels of institutional education. Among these methods there were, for example "The Survivors' Heritage", which consists of passing on the life experience of Holocaust survivors to future generations, either through interviews or through literary memories - this approach is, in our opinion, more applicable to real teaching: for example through the diaries of children and adolescents interned in concentration camps or ghettos. The model can also be applied in the context of the testimony of the survivors of the Nazi extermination machinery of the second or third generation. The application of the model presupposes the testimony of Jewish persons as a starting point. We believe it is very important to enrich this model with testimony from Germans, Nazis and the like. In our opinion, teaching in which both perspectives on the issue will be implemented has the potential to develop pupils' critical thinking, argumentation techniques or the ability to view problems (in the contemporary world) comprehensively.

"The historical approach" it is based on the thesis that pupils learn history through Literary Education. This approach, at the level of a certain amount of necessary fact that pupils and students should acquire, represents a shift from transmitting (and writing) the finished facts to pupils at the expense of active pupil involvement in the search for contexts (constructivist approach).

"Multi-Level Approach" is based on the thesis that building the desired axiological values of pupils, adopting ethical standards or perceiving democracy as a value should begin at the earliest age. Adapting the teaching tool or the means of pupils' age should be a matter of course.

"An Interdisciplinary Approach" assumes that the presentation of the Shoah events by mediating the life of a person in connotation with their anchoring into a historical-social context can lead to a view of the issue from different perspectives. We see the main benefit of this approach in preventing the flattening of the perception of the Shoah as merely an effort to exterminate persons of Jewish nationality.

We are aware that it is not possible to cover all the methods postulated by experts in the field. We have tried to summarize the Shoah presentation procedures, which in our opinion are implementable in real education and which view the issue from different perspectives.

The issue of the Shoah is a rather complicated and abstract theme. We believe that choosing the appropriate method of presentation (given the age of the pupils, their preconceptions and the like) can lead to desirable effects on pupils and students, which can lead to the acceptance of certain general human values (axiological, democratic and the like).

\section{Acknowledgements}

This work was supported by the student project IGA_PdF_2020_002_Compilation and Verification of Monothematic Set of Texts on the Topic of the Shoah of the Palacký University.

\section{References}

Abramovich, D. (2019). Fragments of Hell. Israeli Holocaust Literature. Brighton: Academic Studies Press.

Abrams, I. M. (1997). Elie Wiesel - Nobel Lecture. World Scientific Publishing CO. Retrieved from http://www.nobelprize.org/

Acedo, C. (2010). Lessons from the Shoah for history, memory, and human rights. Prospects, 2010(40), 1-3. https://doi.org/10.1007/s11125-010-9149-3

Bauer, J. (2009). Úvahy o holokaustu (Rethinking the holocaust). Praha: Academia.

Beach, R., Appleman, D., Fecho, B., \& Simon, R. (2016). Teaching Literature to Adolescents. New York: Routledge.

Brazzo, L., \& Schwarz, G. (eds.). (2010). Jews in Europe after the Shoah. Studies and Research Perspectives Introduction. Quest. Issues in Contemporary Jewish History. Journal of Fondazione CDEC, 2010(1), 1-15.

Breitfelder, M. (2019). Kompendium holocaust. Interkulturalita a národnostní menšiny v teorii i praxi. Témata, 
historie, biografie, holocaust. Praha: viaCentrum, 114-160.

Brody, D. (2009). Sailing through Stormy Seas: An Israeli Kindergarten Teacher Confronts Holocaust Remembrance Day. Early Childhood Research \& Practice, 11(2), 1-13.

Brown, L. (2003). Not in Kansas Anymore: Holocaust Films for Children. The Lion and the Unicorn, 27(3), 349-409. https://doi.org/10.1353/uni.2003.0030

Carrier, P. et al. (2015a). The International status of education about the Holocaust: a global mapping of textbooks and curricula; summary. Paris: UNESCO.

Carrier, P. et al. (2015b). The International Status of Education about the Holocaust - A Global Mapping of Textbooks and Curricula. Paris: UNESCO.

Cohen, E. H. (2016). Teacher autonomy within a flexible national curriculum: development of Shoah (holocaust) education in Israeli state school. Curriculum Studies, 48(2), 167-191. https://doi.org/10.1080/00220272.2015.1033464

Drahi, P. (2015). L'expérience de l'enseignement de la Shoah en France par des professeurs de collège et de lycée: un analyseur de l'expertise professionnelle face à une question socialement vive. Thèse de doctorat en Sciences de l'éducation. Paris: École doctorale Connaissance, langage et modélisation (Nanterre).

Dror, Y. (2001). Holocaust Curricula in Israeli Secondary Schools, 1960s-1990s: Historical Evaluation from the Moral Education Perspective. The Journal of Holocaust Education, 10(2), 29-39. https://doi.org/10.1080/17504902.2001.11087129

Due Enstad, J. (2017). Antisemitic Violence in Europe, 2005-2015. Exposure and Perpetrators in France, UK, Germany, Sweden, Denmark and Russia. Oslo: University of Oslo. Retrieved from https://www.duo.uio.no/bitstream/handle/10852/55776/Antisemittisk\%2bvold\%2bi\%2bEuropa engelsk 12.6.1 7.pdf? sequence $=1 \&$ isAllowed $=\mathrm{y}$

Einwohner, R., \& Maher, T. (2011). Threat Assessment and Collective-Action Emergence: Death-Camp and Ghetto Resistance during the Holocaust. Mobilization: An International Quarterly, 16(2), 127-146. https://doi.org/10.17813/maiq.16.2.j263166u14286024

Friedländer, S. (1990). The Shoah between Memory nad History. Jewish Quarterly, 37(1), 5-11. https://doi.org/10.1080/0449010X.1990.10705677

Gasanabo, J. D., Mutanguha, F., \& Mpayimana, A. (2016). Teaching about the Holocaust and Genocide in Rwanda. Contemporary Review of the Middle East, 3(3), 329-345. https://doi.org/10.1177/2347798916654583

Gil, I. (2009). Teaching the Shoah in History Classes in Israeli High Schools. Israel Studies, 14(2), 1-25. https://doi.org/10.1353/is. 0.0029

Grech, L. (2000). Teaching about the Holocaust. Strasbourg: Council for Cultural Co-operation. Retrieved from https://rm.coe.int/1680494240

Gross, Z. (2010). Holocaust education in Jewish schools in Israel: Goals, dilemmas, challenges. Prospects, 40(1), 93-113. https://doi.org/10.1007/s11125-010-9142-x

Hersh, E. (2016). How Can We Teach About the Holocaust to Seven to Ten Year Olds? Undergraduate Honors Thesis Collection. Retrieved from https://digitalcommons.butler.edu/ugtheses/331

Hník, O. (2012). Literární výchova a rozvoj čtenářství. In Wildová, R. (Ed.), Čtenářská gramotnost a podpora jejího rozvoje ve škole. Praha: Univerzita Karlova, 137-147.

Imber, S. (2013). How We Approach Teaching About the Shoah. Yad Vashem. Retrieved from https://www.yadvashem.org/articles/general/pedagogical-philosophy.html

Insdorf, A. (2002). Indelible Shadows. Film and the Holocaust. Cambridge: Press Syndicate of the University of Cambridge.

Jacoby, J. (2016). Forgeting the Holocaust. Aish Ha Torah Literacy. Retrieved from https://www.aish.com/jw/s/Forgetting-the-Holocaust.html

Jennings, L. B. (2015). Holocaust Education and Critical Citizenship in an American Fifth Grade: Expanding Repertoires of Meanings, Language and Action. As the Witnesses Fall Silent: 21st Century Holocaust Education in Curriculum, Policy and Practice. Springer: Cham, 185-208. https://doi.org/10.1007/978-3-319-15419-0 11 
Jindráček, V. et al. (2011). Dětská pojetí uměleckého textu jako východiska školní interpretace. Ústí nad Labem: Univerzita Jana Evangelisty Purkyně.

Jordan, S. D. (2004). Educating Without Overwhelming: Authorial Strategies in Children's Holocaust Literature. Children's Literature in Education, 35(3), 199-217. https://doi.org/10.1023/B:CLID.0000041779.63791.ae

Kaminka, E. (2016). Teaching about the Holocaust in Israel: A Pedagogical Approach Adopted by the Israeli Ministry of Education. Contemporary Review of the Middle East, 3(3), 237-249. https://doi.org/10.1177/2347798916654538

Kerner, A. (2011). Film and the Holocaust. New Perspectives on Dramas, Documentarie, and Experimental Films. New York: The Continuum International Publishing Group.

Kokkola, L. (2003). Representing the Holocaust in Children's Literature. New York: Routledge.

Kraft, D. (2014). How Young Is Too Young to Teach My Child About the Holocaust? Haaretz. Retrieved from https://www.haaretz.com/jewish/teaching-kids-about-the-holocaust-1.5246405

Krejsová, A. (2017). Mediální obraz holokaustu jako kolektivního traumatu: diskursivní analýza vybraných př́běhů preživších z koncentračniho tábora Osvětim. Thesis. Brno: Masaryk University.

Krupp, M. (2013). Dějiny státu Izrael: od založeni do dneška (1948-2013) (Die Deschichte des Staates Israel). Praha: Vyšehrad.

Kryl, M. et al. (2011). Rasismus, antisemitismus, holocaust. Ústí nad Labem: Filozofická fakulta Univerzity Jana Evangelisty Purkyně v Ústí nad Labem.

Lederbuchová, L. (2010). Literatura ve škole. Četba žáka a didaktická interpretace uměleckého textu v literární výchově na 2. stupni základni školy a v odpovidajicich ročnícich víceletého gymnázia. Plzeň: Západočeská univerzita.

Lindquist, D. H. (2010). Complicating Issues in Holocaust Education. Journal of Social Studies Research, 34(1), 77-93.

Lindquist, D. H. (2013). Defining the Shoah: An Opening Lesson for a Holocaust Unit. The Social Studies, 104(1), 32-37. https://doi.org/10.1080/00377996.2012.660212

Lindquist, D. H. (2008). Developing Holocaust Curricula: The Content Decision-Making Process. A Journal of Educational Strategies. Issues and Ideas, 82(1), 27-34. https://doi.org/10.3200/TCHS.82.1.27-34

Malý, R. (2016). Deníková tvorba mladých ve stínu holokaustu. In Čeňková, J. (Ed.), Válečné dětství a mládi (1939-1945) v literatuře a publicistice. Praha: Karolinum, 164-171.

Martin, K. C. (2007). Teaching the Shoah: Four Approaches That Draw Students In. The History teacher, 40(4), 493-502. https://doi.org/10.2307/30037046

Mason-Bish, H., \& Trickett, L. (2019). Introduction to the special issue on the politics of hate: community, societal and global responses. Crime, Law and Social Change, 71(3), 241-243. https://doi.org/10.1007/s10611-019-09816-x

Mašát, M. (2019a). Diaries with the Shoah Theme in Context of Literary Education. JAZYK-LITERATURA-KOMUNIKACE, 2018(1), 26-40.

Mašát, M. (2019b). To Implement the Theme of Shoah in the Teaching of Literary Education from the Point of View of Teachers. Paidagogos, 1(3), 35-61.

Mašát, M. (2017). To the Utilization of the Shoah Theme in the Reading books for the Second Grade of Primary Schools. Jazyk - literatura - komunikace, 2017(2), 68-78.

Mašát, M. (2019c). Methods used by teachers of literary education working with texts in the Shoah theme. 3rd International e-Conference on Studies in Humanities and Social Sciences: Conference Proceedings. Belgrade: Center for Open Access in Science, s. 271-286. https://doi.org/10.32591/coas.e-conf.03.26271m

Mašát, M. (2018). Zastoupení termínů šoa a holokaust ve vybraných kurikulárních dokumentech. Recenzovaný sborník př́spěvků vědecké interdisciplinární mezinárodní vědecké konference doktorandů a odborných asistentů QUAERE. Hradec Králové: Magnanimitas, 802-809.

Mašát, M., \& Sladová, J. (2019). Representations of Shoah and Holocaust Terms in Selected Curriculum Documents: A Teacher's Perspective. Universal Journal of Educational Research, 7(2), 457-462. 
https://doi.org.10.13189/ujer.2019.070218

Mašát, M., \& Šmakalová, K. (2019). The Reception of Selected Texts with the Theme of Shoah among Pupils of the 6th-9th Year in the Primary Schools. Universal Journal of Educational Research, 7(6), 1341-1346. https://doi.org/10.13189/ujer.2019.070601

Medding, P. Y. (2011). Studies in Contemporary Jewry: Volume XIV: Coping with Life and Death: Jewish Families in the Twentieth Century. Oxford: Oxford University Press.

Mémorial de la Shoah. (2017). What is the Shoah? Mémorial de la Shoah. Retrieved fromhttp://www.memorialdelashoah.org/

Moisan, S., Hirsch, S., \& Audet, G. (2015). Holocaust Education in Quebec: Teacher's Positioning and Practices. McGill Journal of Education, 50(2-3), 247-268. https://doi.org/10.7202/1036432ar

Nowel, S. D., \& Poindexter, N. K. (2018). Holocaust education as a path to prepare preservice social studies teachers to be social justice educators. The Journal of Social Studies Research, 43(3), 285-298. https://doi.org/10.1016/j.jssr.2018.03.003

Ofer, D. (1998). Cohesion and Rupture: The Jewish Family in East European Ghettos during the Holocaust. Studies in Contemporary Jewry, 14, 143-165.

Oliveira, W. M. (2017). In Search of Over There: Education, Space, and Language. Educação \& Realidade, 42(3), 1161-1182. https://doi.org/10.1590/2175-623660859

Peroutková, M. (2016). Židovské identity v Československu před 2. Světovou válkou a po ní. Praha: Libri.

Porat, D. A. (2004). From the Scandal to the Holocaust in Israeli Education. Journal of Contemporary History, 39(4), 619-636. https://doi.org/10.1177/0022009404046757

Resnik, J. (2003). 'Sites of memory' of the Holocaust: shaping national memory in the education system in Israel. Nations and Nationalism, 9(2), 297-317. https://doi.org/10.1111/1469-8219.00087

Seeman, M. V. (2020). Anti-Semitism, the Holocaust, and Intergenerational Transmission of Trauma. In: Moffic, H., Peteet, J., Hankir, A., Seeman, M. (Eds.), Anti-Semitism and Psychiatry. Stuttgart: Springer, Cham, pp. 205-220. https://doi.org/10.1007/978-3-030-37745-8_17

Shawn, K., \& Goldfrad, K. (eds.). (2008a). The Call of Memory: Learning About the Holocaust Through Narrative. A Teacher's Guide. Teaneck: Ben Yehuda Press.

Shawn, K., \& Goldfrad, K. (eds.). (2008b). The Call of Memory: Learning About the Holocaust Through Narrative. An anthology. Teaneck: Ben Yehuda Press.

Spiegelman, A. (1991). And Here My Troubles Began. New York: Pantheon.

Spiegelman, A. (1986). My Father Bleeds History. New York: Pantheon.

Spiegelman, A. (1994). The Complete Maus. New York: Voyager.

Ševčíková, E. (2013). Problematika popírání holocaustu v České republice. Acta Universitatis Carolinae Iuridica, 59(2013), 179-192.

Tinberg, H. (2005). Taking (and Teaching) the Shoah Personally. College English, 68(1), 72-89. https://doi.org/10.2307/30044665

Tinberg, H., \& Weisberger, R. (2014). Teaching, Learning and the Holocaust. An Integrative Apprach. Bloomington: Indiana University Press.

Unterman, S. M. (2016). How Do You Teach the Holocaust to Kids Who've Never Heard of It? Forward. Retrieved from https://forward.com/culture/348921/how-do-you-teach-the-holocaust-to-kids-whove-never-heard-of-it/

Urbanová, S. (2018). S holokaustem za zády. Téma holokaustu v české a překladové literatuře pro děti a mládež vydávané po roce 1989. Ostrava: Ostravská univerzita

Von Borries, B. (2017). Learning and teaching about the Shoah: retrospect and prospect. Holocaust Studies. $A$ Journal of Culture and History, 23(3), 425-440. https://doi.org/10.1080/17504902.2017.1298348

Website of the International Holocaust Remembrance Alliance (IHRA). Retrieved from https://www.holocaustremembrance.com

Website of the Parliament of the Czech Republic.Retrieved from https://www.psp.cz/sqw/hp.sqw?akk=7 
Website of the United States Holocaust Memorial Museum.Retrieved from https://www.ushmm.org/

Wiesel, E. (2007). Paměti 2: všechny řeky jdou do moře, moře se však nenaplní-. (--et la mer n’est pas remplie). Hodkovičky [Praha]: Pragma.

Ziv, Y., Golden, D., \& Goldberg, T. (2015). Teaching Traumatic History to Young Children: The Case of Holocaust Studies in Israeli Kindergartens. Early Education and Development, 26(4), 520-533. https://doi.org/10.1080/10409289.2015.1000719 